\title{
Response of diamine oxidase and other plasma copper biomarkers to various dietary copper intakes in the rat and evaluation of copper absorption with a stable isotope
}

\author{
C. Feillet-Coudray*, C. Coudray, D. Bayle, E. Rock, Y. Rayssiguier and A. Mazur \\ Centre de Recherche en Nutrition Humaine d'Auvergne, Unité Maladies Métaboliques et Micronutriments, \\ INRA, Theix, 63122 St-Genès-Champanelle, France
}

(Received 5 August 1999 - Revised 7 October 1999 - Accepted 20 October 1999)

\begin{abstract}
There is a lack of agreement on index of $\mathrm{Cu}$ status and reliable and sensitive biomarkers are still required. The purpose of this present work was to assess in rats the sensitivity of diamine oxidase (DAO) activity, a recently proposed biomarker, to modifications in dietary $\mathrm{Cu}$ intake in comparison with other plasma biomarkers of $\mathrm{Cu}$ status. We also evaluated the effect of $\mathrm{Cu}$ dietary level on $\mathrm{Cu}$ and $\mathrm{Zn}$ intestinal absorption. Results showed that plasma $\mathrm{Cu}$ and plasma caeruloplasmin were significantly decreased at day 8 compared with the control group ( $7.4 \mathrm{mg} \mathrm{Cu} / \mathrm{kg}$ diet) while DAO activity was significantly decreased at day 12 of the deficient diet $(0.61 \mathrm{mg} \mathrm{Cu} / \mathrm{kg}$ diet $) . \mathrm{Cu}$ supplementation $(35 \mathrm{mg} \mathrm{Cu} / \mathrm{kg}$ diet) had no effect on any of the studied biomarkers of $\mathrm{Cu}$ status. In $\mathrm{Cu}$-deficient rats plasma $\mathrm{Cu}$ and DAO activities were normalized $4 \mathrm{~d}$ after return to the control diet while caeruloplasmin was normalized later, at day 11. Apparent absorption values (\%) of total $\mathrm{Cu}$ or ${ }^{65} \mathrm{Cu}$ isotope were significantly increased in the $\mathrm{Cu}$-deficient rats compared with the other groups and similar in the control and the $\mathrm{Cu}$-supplemented groups. The urinary excretion of total $\mathrm{Cu}$ or ${ }^{65} \mathrm{Cu}$ isotope were increased in the $\mathrm{Cu}$-supplemented group compared with the other two groups. Both apparent absorption and urinary excretion of total $\mathrm{Zn}$ or ${ }^{67} \mathrm{Zn}$ isotope remained unchanged in the three experimental groups. In conclusion, DAO activity seemed to be less sensitive to $\mathrm{Cu}$ deficiency than plasma $\mathrm{Cu}$ or caeruloplasmin concentrations. The present study also showed a significant increase in $\mathrm{Cu}$ intestinal absorption with dietary $\mathrm{Cu}$ restriction but no decrease with $\mathrm{Cu}$ supplementation in the rat.
\end{abstract}

Copper: Diamine oxidase: Stable isotopes

$\mathrm{Cu}$ is an essential trace element that plays an important role in the maintenance of optimal health. It is required in various cellular functions, to help normal cellular homeostasis and for the structure and function of skeletal, cardiovascular, nervous and immune systems (Strain, 1994). Cu is involved as a co-factor in various enzyme catalysing oxidation-reduction reactions (Linder \& Hazegh-Azam, 1996). It has been suggested that $\mathrm{Cu}$ deprivation contributes to an increased risk of heart disease through instability of heart rhythm, hyperlipidaemia, increased thrombosis and breakdown of vascular tissue (Klevay, 1990). Cu deficiency may also result in anaemia, leucopaenia and skeletal demineralization. Several studies have shown that $\mathrm{Cu}$ requirements may not be covered by diet Cu (Klevay et al. 1979, 1993; Pennington \& Young, 1991). However, there is a lack of agreement on an index of $\mathrm{Cu}$ nutritional status that is able to track $\mathrm{Cu}$ status in human subjects (Milne \& Johnson, 1993; Milne, 1994). Currently, plasma $\mathrm{Cu}$ or levels of caeruloplasmin or activity of erythrocyte superoxide dismutase (SOD) are commonly used to assess $\mathrm{Cu}$ status in studies with human subjects. Caeruloplasmin is a plasma glycoprotein, primarily synthesized in the liver and secreted into the blood which binds more than $60 \%$ of plasma $\mathrm{Cu}$ and is considered a $\mathrm{Cu}$ transport protein (Linder, 1991). Erythrocyte SOD is an important intracellular enzyme that requires both $\mathrm{Cu}$ and $\mathrm{Zn}$ for normal enzyme activity. However, none of these measurements change quickly in response to intentional induction of mild $\mathrm{Cu}$ deficiency in human subjects (Danks, 1988). In addition, readings for these measurements tend to be elevated by many physiological stress states including inflammation, cancer, chronic exercise, pregnancy and lactation (Danks, 1988). This limits the usefulness of these biochemical measures as diagnostic indicators of marginal $\mathrm{Cu}$ deficiency. Therefore, reliable and sensitive functional measures of marginal $\mathrm{Cu}$ deficiency are required. 
Recently, diamine oxidase (DAO), a Cu-dependent enzyme, has been proposed as a valuable biomarker of $\mathrm{Cu}$ status in human subjects and in animals (DiSilvestro et al. 1997; Jones et al. 1997; O'Connor et al. 1999). DAO is an enzyme catalysing the oxidation of diamines such as histamine, putrescine and cadaverine (Wolvekamp \& de Bruin, 1994). It is normally abundant within the intestinal mucosa, kidney and placenta, but scant in serum (Kusche et al. 1974; Tam et al. 1979; Luk et al. 1980; D'Agostino et al. 1984). DiSilvestro's group has reported high plasma DAO activities in patients undergoing renal dialysis and in some adult men receiving $\mathrm{Cu}$ supplementation, and low activities during spontaneous Cu deficiency (DiSilvestro et al. 1997; Jones et al. 1997). Moreover, the results of the European FoodCue project demonstrated high levels of plasma DAO activity with $\mathrm{Cu}$ supplementation in human subjects (O'Connor et al. 1999). Low activities were also seen in marginally Cu-deficient rats (DiSilvestro et al. 1997).

$\mathrm{Cu}$ status may be largely affected by intestinal absorption and retention of $\mathrm{Cu}$. Several studies on rats have investigated the effects of various factors on $\mathrm{Cu}$ absorption and retention. The effects of naturally occurring $\mathrm{Cu}$ complexes (Mills, 1986), protein source (Lo et al. 1984), dietary $\mathrm{Zn}: \mathrm{Cu}$ ratio (Oestreicher \& Cousins, 1985) and fibre (Scheibel \& Mehta, 1985) on $\mathrm{Cu}$ absorption in the rat have been reported. However, there is only one report dealing with the $\mathrm{Cu}$ absorption as function of $\mathrm{Cu}$ intakes in rats (Stuart \& Johnson, 1986). It is therefore of great importance to look simultaneously at the intestinal absorption of $\mathrm{Cu}$ in this present study to better understand and interpret our result on $\mathrm{Cu}$ status.

The purposes of this present work were: (1) to assess the sensitivity of DAO to modifications in dietary $\mathrm{Cu}$ intake in comparison with other plasma biomarkers of $\mathrm{Cu}$ status; (2) to evaluate the effect of different levels of $\mathrm{Cu}$ in the diet on $\mathrm{Cu}$ and $\mathrm{Zn}$ intestinal absorption.

\section{Materials and methods}

\section{Reagents and materials}

Enriched ${ }^{65} \mathrm{Cu}$ and ${ }^{67} \mathrm{Zn}$ isotopes in the oxide form were obtained from Eurisotope (Saint-Aubin, France). Suprapure $\mathrm{HNO}_{3}, \mathrm{HCl}$ and $\mathrm{H}_{2} \mathrm{O}_{2}$ were purchased from Merck (Darmstadt, Germany). All other chemicals were of the highest quality available and demineralized water was used throughout the study. The inductively-coupled plasma mass spectrometer used to measure stable isotope enrichments was a Plasmaquad II system (Fisons Instruments, Manchester, UK) equipped with a Meinhard (Santa Ana, CA, USA) nebulizer. The atomic absorption spectrometer (Perkin Elmer 560, St Quentin en Yvelines, France) was used for total $\mathrm{Cu}$ and $\mathrm{Zn}$ measurements.

\section{Animals, diets and experimental design}

Male Wistar rats (IFFA-CREDO, L'Arbresle, France) weighing about $500 \mathrm{~g}$ were used. The rats were housed under conditions of constant temperature $\left(20-22^{\circ}\right)$, humidity (45$50 \%$ ) and a standard light-dark cycle (dark 20.00-08.00 hours). Rats first went through an adaptation period of $10 \mathrm{~d}$ with free access to a semi-purified diet (control diet) and demineralized water. Rats were then randomized into three groups of eight animals and each fed for a 3-week period either on the control diet (control group), the control diet without $\mathrm{Cu}(\mathrm{Cu}$-deficient group) or the control diet supplemented with $\mathrm{Cu}$ ( $\mathrm{Cu}$-supplemented group). After 3 weeks, the rats were fed again on the control diet for $11 \mathrm{~d}$. The semipurified diets contained the following $(\mathrm{g} / \mathrm{kg})$ : casein 200, starch 650, maize oil 50, alphacel 50, DL-methionine 3, choline bitartrate 2, modified AIN-93 mineral mix 35, AIN93A vitamin mix 10 (ICN Biomedicals, Orsay, France). Cupric carbonate was omitted from the AIN-93 mineral mix for the deficient diet and $52.2 \mathrm{mg}$ cupric carbonate $(27.1 \mathrm{mg}$ $\mathrm{Cu}$ ) was added for the supplemented diet. Blood samples were collected at the retro-orbital sinus after brief anaesthesia with diethyl ether after 4, 8, 12 and $18 \mathrm{~d}$ from control, $\mathrm{Cu}$-deficient or $\mathrm{Cu}$-supplemented animals, and then 4 and $11 \mathrm{~d}$ after returning to the control diet. Blood was drawn into a heparinized tube $(1 \mathrm{ml})$ and also into a glass tube without anticoagulant $(1 \mathrm{ml})$ and allowed to clot. Then plasma and serum were obtained by centrifugation. Packed cell volume was determined by centrifugation in a capillary tube system to obtain packed cells. Haemoglobin was evaluated by a colorimetric method (Boehringer Mannheim, Mannheim, Germany).

The total $\mathrm{Cu}$ and the ${ }^{65} \mathrm{Cu}$ intestinal absorption were evaluated at the end of the supplemented or deficient experimental period, just before switching to the control diet. For this purpose, ${ }^{65} \mathrm{Cu}$ and ${ }^{67} \mathrm{Zn}$ stable isotopes were administered orally and faeces and urine were collected every day for three successive days. Food intake for each animal was evaluated daily during this period. ${ }^{65} \mathrm{CuO}$ and ${ }^{67} \mathrm{ZnO}$ were transformed into the chloride form before administration orally to the rats.

All procedures were in agreement with the Institute's guide for care and use of laboratory animals.

\section{Copper status}

The activity of caeruloplasmin in serum was determined according to the method of Sunderman \& Nomoto (1970). At $\mathrm{pH} 5.4$, caeruloplasmin catalyses the oxidation of $p$ phenylenediamine to yield a coloured product (absorbance $530 \mathrm{~nm}$ ). The rate of formation of the coloured oxidation product is proportional to the concentration of serum caeruloplasmin after correction for non-enzymic oxidation of $p$ phenylenediamine.

The serum DAO was determined according to the method of Takagi et al. (1994) with the following modifications: $750 \mu \mathrm{l}$ cadaverine solution $(30 \mathrm{mmol} / \mathrm{l})$ at $37^{\circ}$ are added to150 $\mu \mathrm{l}$ serum sample and the mixture is incubated at $37^{\circ}$ for exactly $30 \mathrm{~min}$. Then, $750 \mu \mathrm{l} 10$-(carboxymethylaminocarbonyl)-3,7-bis(dimethylamino)phenothiazine sodium salt $100 \mu \mathrm{mol} / \mathrm{l}$, horseradish peroxidase; (600 U/l)-ascorbate oxidase; (500 U/l) solution are added, mixed and incubated further. Immediately after the incubation of $90 \mathrm{~min}, 25 \mu \mathrm{l}$ sodium diethylcarbamate solution are added to stop the reaction. Then the absorbance of methylene blue at $668 \mathrm{~nm}$ is recorded.

Plasma and urinary $\mathrm{Cu}$ levels were determined by atomic absorption spectrophotometry at $325 \mathrm{~nm}$, as described previously (Bellanger, 1971). 
Balances of total $\mathrm{Cu}$ and ${ }^{65} \mathrm{Cu}$, and of total $\mathrm{Zn}$ and ${ }^{67} \mathrm{Zn}$

After 3 weeks on the different experimental diets, $2 \mathrm{ml}$ solution containing ${ }^{65} \mathrm{Cu}$ and ${ }^{67} \mathrm{Zn}$ stable isotope was administered orally to the rats. This solution contained either 10,100 or $500 \mu \mathrm{g}{ }^{65} \mathrm{Cu}$ and $100 \mu \mathrm{g}{ }^{67} \mathrm{Zn}$ for $\mathrm{Cu}$-deficient, control and $\mathrm{Cu}$-supplemented groups respectively. Administered ${ }^{65} \mathrm{Cu}$ isotope was thus proportional to the amount of $\mathrm{Cu}$ ingested by the rats in each experimental group.

Faeces and urine were collected into trace element-free containers over $3 \mathrm{~d}$ periods after isotope administration. Individual faeces samples were freeze-dried and powdered. Sub-samples of diet $(1 \mathrm{~g})$ or powdered faeces $(0.25 \mathrm{~g})$ were ashed at $500^{\circ}$ for $10 \mathrm{~h}$. The ashes were dissolved in $0.2 \mathrm{ml}$ $14 \mathrm{M}-\mathrm{HNO}_{3}$ and $0 \cdot 1 \mathrm{ml} \mathrm{H}_{2} \mathrm{O}_{2}$ and heated for $2 \mathrm{~h}$ at $100^{\circ}$ on a hotplate and diluted appropriately with $0 \cdot 14 \mathrm{M}-\mathrm{HNO}_{3}$.

Urine volume was determined and $10 \mathrm{ml}$ urine was acidified with $0 \cdot 1 \mathrm{ml} 14 \mathrm{M}-\mathrm{HNO}_{3}$. $\mathrm{Cu}$ - and $\mathrm{Zn}$ isotope ratios were determined in urine as previously described (Coudray et al. 1998). $\mathrm{Cu}$ and $\mathrm{Zn}$ isotope ratios were determined in urine and faeces by inductively-coupled plasma mass spectrometry using $\mathrm{Cu}$ and $\mathrm{Zn}$ solutions as external standards. Total $\mathrm{Cu}$ and $\mathrm{Zn}$ concentrations were determined in plasma, urine and faeces by atomic absorption spectrometry (PerkinElmer 560) in an acetylene-air flame at the following wavelengths (nm): $324.7(\mathrm{Cu})$ and 213.8 (Zn). Appropriate quality controls (Seronorm serum, Nycomed, Oslo, Norway) were run with each set of measurements. Conventional chemical balance and isotopic balance were also determined according to the following equation: ingested amount(excretion in the faeces + urine).

\section{Statistical analysis}

Results were expressed as means with standard errors. The statistical significance of differences between means was assessed by one way ANOVA followed by a Student Newman Keuls test. The limit of statistical significance was set at $P<0.05$.

\section{Results}

The analysis of diets gave the following levels of $\mathrm{Cu}$ : $0.61 \mathrm{mg} / \mathrm{kg}$ (deficient diet), $7.4 \mathrm{mg} / \mathrm{kg}$ (control diet) and $35.0 \mathrm{mg} / \mathrm{kg}$ (supplemented diet). The $\mathrm{Zn}$ concentrations were $53,52.9$ and $53.4 \mathrm{mg} / \mathrm{kg}$ respectively.

Mean body weight of rats was unchanged during all the study for each group (Table 1). Packed cell volumes and haemoglobin levels were not affected by $\mathrm{Cu}$ deficiency nor by supplementation (Table 1).

Plasma $\mathrm{Cu}$ (Fig. 1) and plasma caeruloplasmin (Fig. 2) were significantly decreased in the $\mathrm{Cu}$-deficient group at day 8 compared with the control group. DAO activity was significantly decreased only after day 12 on the deficient diet (Fig. 3). In $\mathrm{Cu}$-deficient rats plasma $\mathrm{Cu}$ and DAO activities were normalized $4 \mathrm{~d}$ after return to the control diet while caeruloplasmin was normalized later, at day 11 . $\mathrm{Cu}$ supplementation had no effect on any of the studied biomarkers of $\mathrm{Cu}$ status (Figs 1-3).

Intra-run CV for caeruloplasmin measurement was $4.6 \%$. Intra- and inter-run $\mathrm{CV}$ for plasma and urinary $\mathrm{Cu}$ measurements were $2.4 \%, 4.3 \%$ (plasma) and $3.5 \%, 6.5 \%$ (urine) respectively. Those of plasma and urinary $\mathrm{Zn}$ measurements were as follows: $2.1 \%, 3.7 \%$ (plasma) and $3.4 \%, 5.2 \%$ (urine) respectively.

$\mathrm{Cu}$ and $\mathrm{Zn}$ absorption for each dietary $\mathrm{Cu}$ intake are shown in Tables 2 and 3, and in Tables 4 and 5 respectively. Values for apparent absorption $(\%)$ of total $\mathrm{Cu}$ or ${ }^{65} \mathrm{Cu}$ isotope were similar in the control and the $\mathrm{Cu}$-supplemented groups. However, both absorption values were significantly increased in the $\mathrm{Cu}$-deficient rat group compared with the other groups. Moreover, ${ }^{65} \mathrm{Cu}$ isotope absorption was higher than the total $\mathrm{Cu}$ absorption in the $\mathrm{Cu}$-deficient group. The urinary excretion of both total $\mathrm{Cu}$ or ${ }^{65} \mathrm{Cu}$ isotope were increased in the $\mathrm{Cu}$-supplemented group compared with the two other experimental groups. Both apparent absorption of total $\mathrm{Zn}$ or ${ }^{67} \mathrm{Zn}$ isotope and urinary excretion of total $\mathrm{Zn}$ or ${ }^{67} \mathrm{Zn}$ isotope remained unchanged in the three experimental groups.

\section{Discussion}

This present study explored serum DAO activity, a recently proposed biomarker of $\mathrm{Cu}$ status (DiSilvestro et al. 1997; Jones et al. 1997; O'Connor et al. 1999), and compared it with other usual plasma indices such as plasma $\mathrm{Cu}$ and serum caeruloplasmin during modifications in $\mathrm{Cu}$ dietary intake. The potential changes were followed at day 4, 8, 12 and 18 on Cu-deficient $(0 \cdot 61 \mathrm{mg} / \mathrm{kg})$ and $\mathrm{Cu}$-supplemented diets $(35 \mathrm{mg} / \mathrm{kg})$. After this $18 \mathrm{~d}$ period and before the return to control diet, $\mathrm{Cu}$ and $\mathrm{Zn}$ intestinal absorption studies were performed. We then studied the effect of return to the control diet in all the rats.

Table 1. Characteristics of rats fed on either the control, the Cu-supplemented or the Cu-deficient diet for $18 \mathrm{~d}^{*}$ (Values are means with standard errors for eight rats per group)

\begin{tabular}{|c|c|c|c|c|c|c|}
\hline & \multicolumn{2}{|c|}{ Control diet } & \multicolumn{2}{|c|}{ Supplemented diet } & \multicolumn{2}{|c|}{ Deficient diet } \\
\hline & Mean & SE & Mean & SE & Mean & SE \\
\hline Food intake (g/d) & $22 \cdot 7^{a}$ & 1.1 & $22 \cdot 9^{a}$ & 1.2 & $20 \cdot 4^{a}$ & 1.4 \\
\hline Initial body weight (g) & $494^{\mathrm{a}}$ & 13 & $515^{\mathrm{a}}$ & 15 & $493^{\mathrm{a}}$ & 23 \\
\hline Final body weight $(\mathrm{g})$ & $491^{\mathrm{a}}$ & 5 & $515^{\mathrm{a}}$ & 5 & $501^{\mathrm{a}}$ & 9 \\
\hline Packed cell volume (\%) & $43^{a}$ & 2 & $44^{\mathrm{a}}$ & 2 & $44^{\mathrm{a}}$ & 2 \\
\hline Haemoglobin (g/l erythrocytes) & $430^{\mathrm{a}}$ & 25 & $423^{\mathrm{a}}$ & 31 & $458^{\mathrm{a}}$ & 39 \\
\hline
\end{tabular}

${ }^{a}$ Mean values within a row with unlike superscript letters were significantly different $(P<0.05)$.

${ }^{*}$ For details of diets see p. 562. 


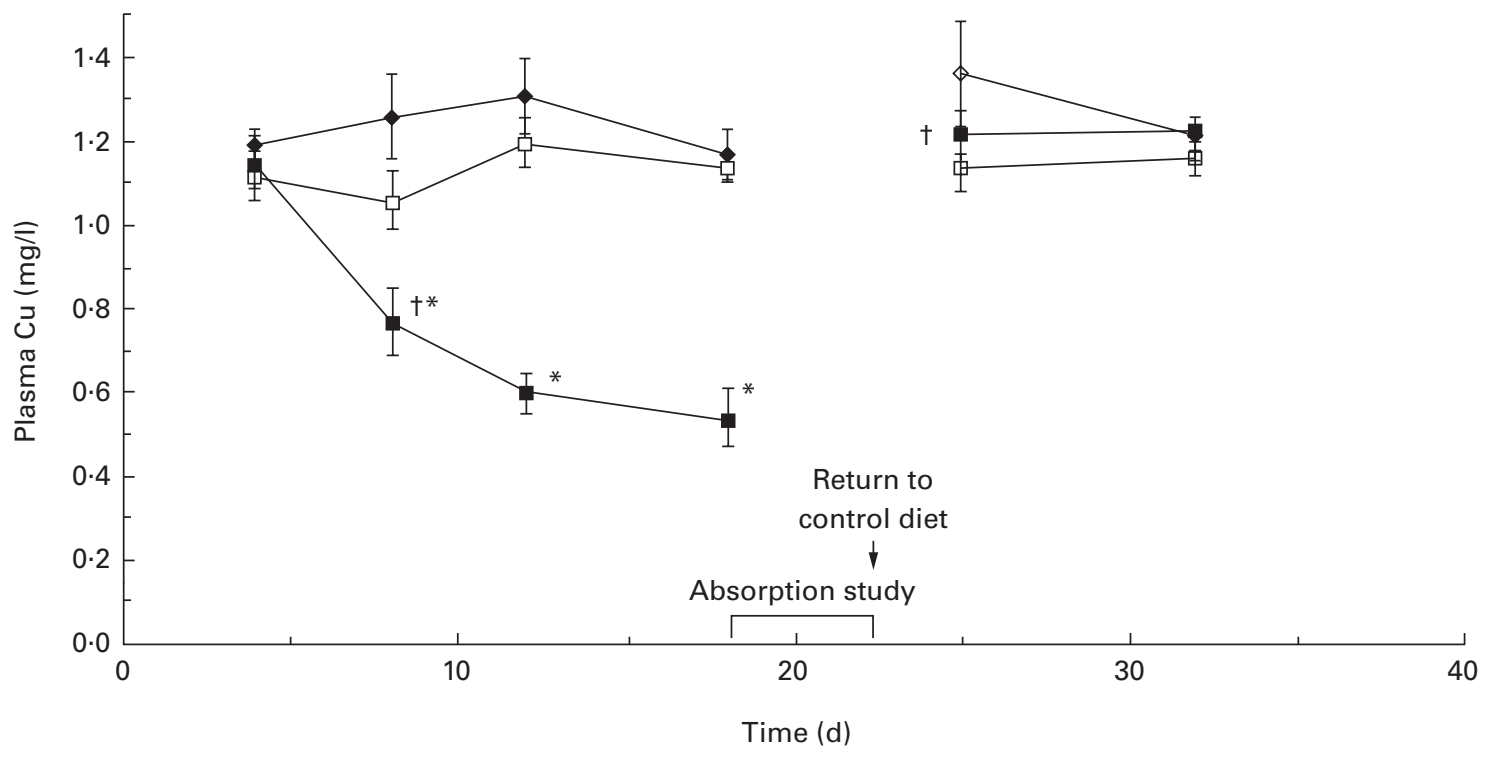

Fig. 1. Time courses of changes in plasma copper in rats ( $n 8$ per group) fed on control ( $\square, 7.4 \mathrm{mg} \mathrm{Cu} / \mathrm{kg}$ ), copper-supplemented ( $\bullet, 35 \mathrm{mg}$ Cu/kg) or copper-deficient $(\boldsymbol{\square}, 0.61 \mathrm{mg} \mathrm{Cu} / \mathrm{kg}$ ) diets for 3 weeks and then returned to the control diet. Values are means with standard errors represented by vertical bars. Mean values were significantly different from control group, ${ }^{*} P<0.05$, and from the mean value for the copper-deficient group on the previous occasion, $\uparrow P<0.05$.

In the first part of this study, we demonstrated that DAO activities decreased significantly during low- $\mathrm{Cu}$ diet consumption, and then increased in response to $\mathrm{Cu}$ repletion. However, plasma $\mathrm{Cu}$ and serum caeruloplasmin reacted more rapidly to $\mathrm{Cu}$ intake than did DAO activity. Thus, DAO activity appeared to be less sensitive to $\mathrm{Cu}$ intake than the two other biomarkers studied. To evaluate the true $\mathrm{Cu}$ status, it is better to evaluate cellular biomarkers as intracellular $\mathrm{Cu}$ (liver) or erythrocyte SOD activity. In this study we were not able to measure liver $\mathrm{Cu}$ because we wanted to follow the plasma $\mathrm{Cu}$ variables in the same groups at the indicated times and thus animals were killed at the end of the experiment. Concerning erythrocyte SOD, this biomarker is known to respond more slowly to modifications of $\mathrm{Cu}$ intake because of the length of the erythrocyte half-life. As we were interested in early modification of $\mathrm{Cu}$ status, we did not evaluate this variable.

Surprisingly, none of the indices of $\mathrm{Cu}$ status studied responded to $\mathrm{Cu}$ supplementation. This is in agreement with results from the study of $\mathrm{Cu}$ supplementation in healthy

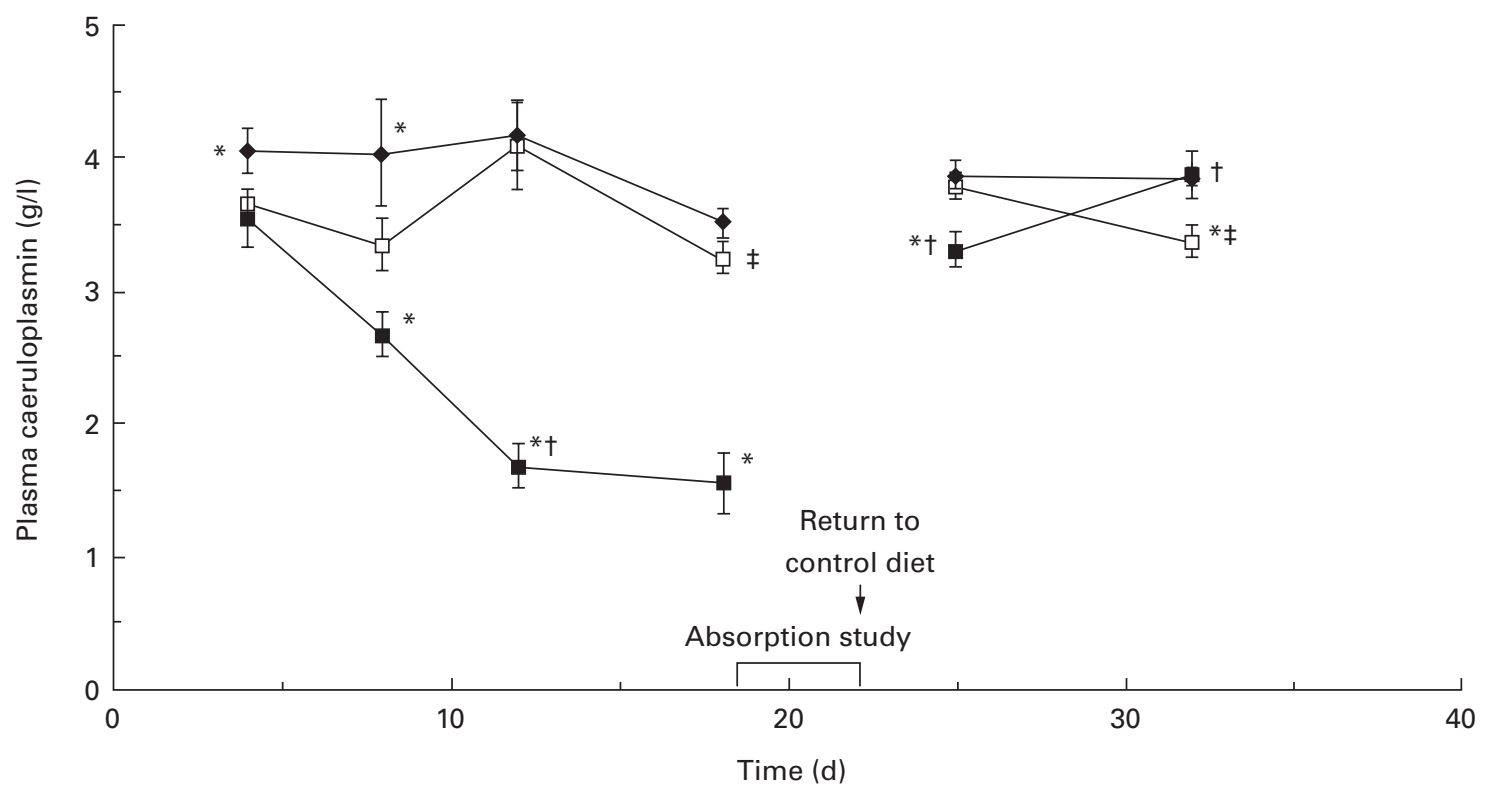

Fig. 2. Time courses of changes in plasma caeruloplasmin in rats ( $n 8$ per group) fed on control $(\square, 7.4 \mathrm{mg} \mathrm{Cu} / \mathrm{kg}$ ), copper-supplemented ( $\bullet, 35 \mathrm{mg}$ $\mathrm{Cu} / \mathrm{kg})$ or copper-deficient $(\mathbf{\square}, 0.61 \mathrm{mg} \mathrm{Cu} / \mathrm{kg})$ diets for 3 weeks and then returned to the control diet. Values are means with standard errors represented by vertical bars. Mean values were significantly different from control group, ${ }^{\star} P<0.05$, and from the mean value for copper-deficient group on the previous occasion, $\dagger P<0.05$, and from the mean value for the control group on the previous occasion, $\ddagger P<0.05$. 


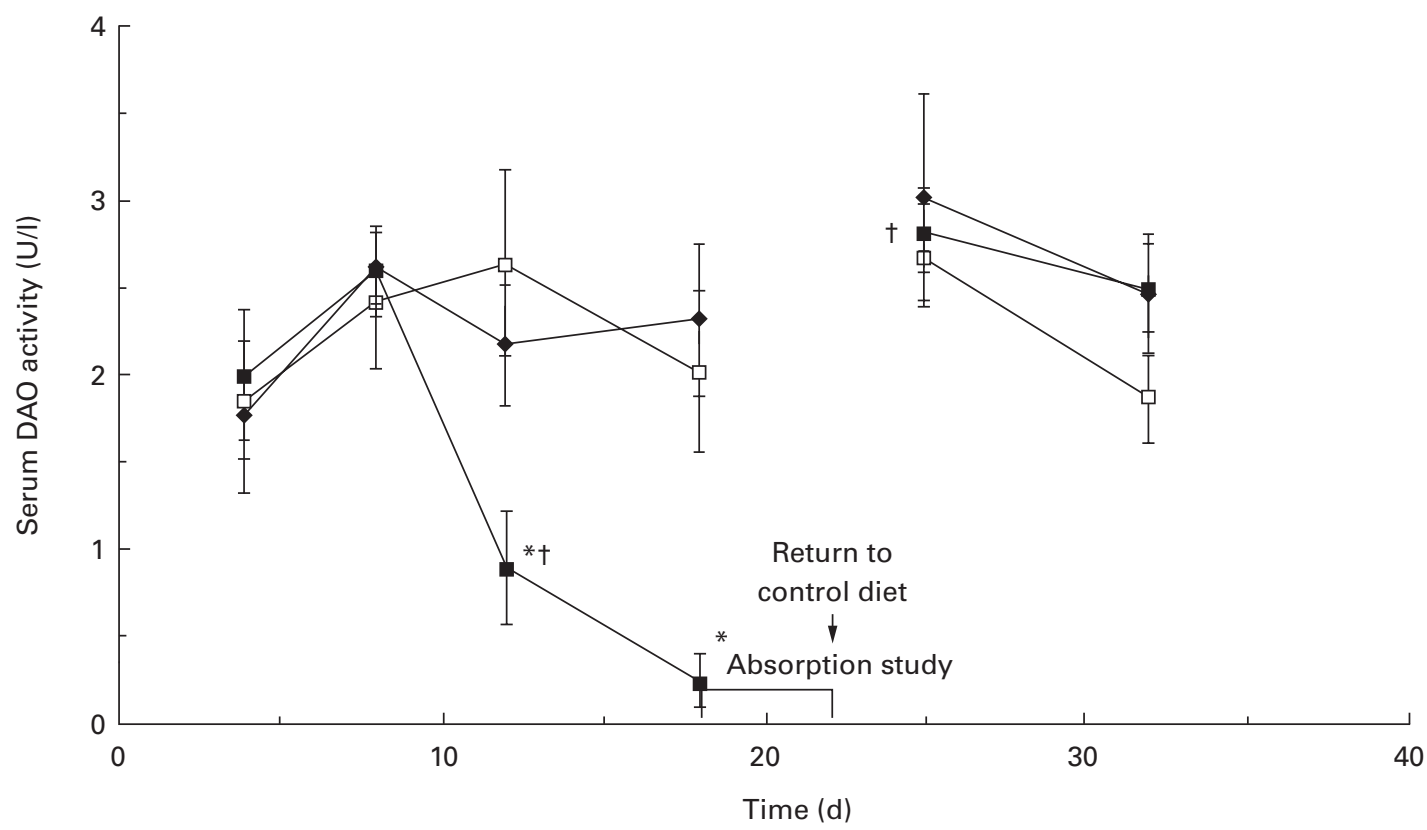

Fig. 3. Time courses of changes in serum diamine oxidase (DAO) in rats ( $n 8$ per group) fed on control ( $\square, 7.4 \mathrm{mg} \mathrm{Cu} / \mathrm{kg}$ ), copper-supplemented $(\diamond, 35 \mathrm{mg} \mathrm{Cu} / \mathrm{kg}$ ) or copper-deficient $(\mathbf{\square}, 0.61 \mathrm{mg} \mathrm{Cu} / \mathrm{kg})$ diets for 3 weeks and then returned to the control diet. Values are means with standard errors represented by vertical bars. Mean values were significantly different from control group, ${ }^{*} P<0.05$, and from the mean value for the copperdeficient group on the previous occasion, $\uparrow P<0.05$.

infants (Salmenpera et al. 1989). We can assume that the $\mathrm{Cu}$ level in the control diet is sufficient to replenish all the pools of $\mathrm{Cu}$ in the rat. Knowing that high plasma DAO activities were observed in patients undergoing renal dialysis (DiSilvestro et al. 1997), in pregnancy and gestational diseases (Kusche et al. 1974) and that DAO activity is also affected by several diseases of the small intestine, the usefulness of this biochemical marker as a diagnostic indicator of marginal
$\mathrm{Cu}$ deficiency appeared to be limited in the rat or at least questionable. Moreover, preliminary results in our laboratory demonstrated that in healthy human subjects these levels were often nil $(<1 \mathrm{U} / \mathrm{l})$ making the exploration of $\mathrm{Cu}$ deficiency difficult. In the rat, DAO levels are higher than in human subjects but still low, making its measurement difficult. Its sensitivity to temperature and storage is another limitation of this biomarker.

Table 2. Effect of different dietary intakes of copper on intestinal absorption and balance of total copper in rats (classical absorption and balance)* (Values are means and standard errors for eight rats per group)

\begin{tabular}{|c|c|c|c|c|c|c|c|c|c|c|c|c|}
\hline \multirow[b]{2}{*}{ Dietary Cu (mg/kg) } & \multicolumn{2}{|c|}{$\begin{array}{l}\text { Cu intake } \\
(\mu \mathrm{g} / \mathrm{d})\end{array}$} & \multicolumn{2}{|c|}{$\begin{array}{c}\text { Faecal Cu } \\
(\mu \mathrm{g} / \mathrm{d})\end{array}$} & \multicolumn{2}{|c|}{$\begin{array}{l}\text { Cu absorption } \\
(\%)\end{array}$} & \multicolumn{2}{|c|}{$\begin{array}{l}\text { Cu absorption } \\
(\mu \mathrm{g} / \mathrm{d})\end{array}$} & \multicolumn{2}{|c|}{$\begin{array}{l}\text { Urinary Cu } \\
(\mu \mathrm{g} / \mathrm{d})\end{array}$} & \multicolumn{2}{|c|}{$\begin{array}{c}\text { Cu balance } \\
(\mu \mathrm{g} / \mathrm{d})\end{array}$} \\
\hline & Mean & SE & Mean & SE & Mean & SE & Mean & SE & Mean & SE & Mean & SE \\
\hline $\begin{array}{l}0.61 \\
7.41 \\
35.0\end{array}$ & $\begin{array}{l}13 \cdot 7^{\mathrm{a}} \\
173^{\mathrm{b}} \\
864^{\mathrm{c}}\end{array}$ & $\begin{array}{l}1 \cdot 2 \\
10 \\
32\end{array}$ & $\begin{array}{c}5 \cdot 9^{a} \\
119^{b} \\
577^{c}\end{array}$ & $\begin{array}{r}0.5 \\
6 \cdot 1 \\
41\end{array}$ & $\begin{array}{l}48 \cdot 4^{\mathrm{a}} \\
31 \cdot 0^{\mathrm{b}} \\
33 \cdot 1^{\mathrm{b}}\end{array}$ & $\begin{array}{l}4.3 \\
1.8 \\
4.6\end{array}$ & $\begin{array}{r}6 \cdot 7^{\mathrm{a}} \\
54 \cdot 4^{\mathrm{b}} \\
287^{\mathrm{c}}\end{array}$ & $\begin{array}{r}1 \cdot 0 \\
5 \cdot 3 \\
42\end{array}$ & $\begin{array}{l}2 \cdot 6^{\mathrm{a}} \\
3 \cdot 9^{\mathrm{a}} \\
7 \cdot 0^{\mathrm{b}}\end{array}$ & $\begin{array}{l}0 \cdot 1 \\
0 \cdot 3 \\
1.2\end{array}$ & $\begin{array}{r}5 \cdot 2^{\mathrm{a}} \\
50 \cdot 5^{\mathrm{b}} \\
280^{\mathrm{c}}\end{array}$ & $\begin{array}{r}1.2 \\
5 \cdot 4 \\
42\end{array}$ \\
\hline
\end{tabular}

a,b,c Mean values within a column with unlike superscript letters were significantly different $(P<0.05)$.

${ }^{*}$ For details of diets see p. 562.

Table 3. Effect of different dietary intakes of copper on intestinal absorption and balance of ${ }^{65}$ copper isotope in rats (isotope absorption and balance)*

(Values are means and standard errors for eight rats per group)

\begin{tabular}{|c|c|c|c|c|c|c|c|c|c|c|c|}
\hline \multirow[b]{2}{*}{ Dietary Cu (mg/kg) } & \multirow{2}{*}{$\begin{array}{c}{ }^{65} \mathrm{Cu} \text { intake } \\
(\mu \mathrm{g} / \mathrm{d})\end{array}$} & \multicolumn{2}{|c|}{$\begin{array}{c}\text { Faecal }{ }^{65} \mathrm{Cu} \\
(\mu \mathrm{g} / \mathrm{d})\end{array}$} & \multicolumn{2}{|c|}{$\begin{array}{c}{ }^{65} \mathrm{Cu} \text { absorption } \\
(\%)\end{array}$} & \multicolumn{2}{|c|}{$\begin{array}{c}{ }^{65} \mathrm{Cu} \text { absorption } \\
(\mu \mathrm{g} / \mathrm{d})\end{array}$} & \multicolumn{2}{|c|}{$\begin{array}{c}\text { Urinary }{ }^{65} \mathrm{Cu} \\
(\mu \mathrm{g} / \mathrm{d})\end{array}$} & \multicolumn{2}{|c|}{$\begin{array}{c}{ }^{65} \mathrm{Cu} \text { balance } \\
(\mu \mathrm{g} / \mathrm{d})\end{array}$} \\
\hline & & Mean & SE & Mean & SE & Mean & SE & Mean & SE & Mean & SE \\
\hline $\begin{array}{l}0.61 \\
7.41 \\
35 \cdot 0\end{array}$ & $\begin{array}{r}11 \cdot 4^{\mathrm{a}} \\
101 \cdot 5^{\mathrm{b}} \\
514^{\mathrm{c}}\end{array}$ & $\begin{array}{r}3 \cdot 6^{a} \\
75 \cdot 2^{b} \\
416^{c}\end{array}$ & $\begin{array}{l}0.5 \\
1.4 \\
15\end{array}$ & $\begin{array}{l}64 \cdot 0^{\mathrm{a}} \\
25 \cdot 9^{\mathrm{b}} \\
19 \cdot 1^{\mathrm{c}}\end{array}$ & $\begin{array}{l}1.7 \\
1.3 \\
2.9\end{array}$ & $\begin{array}{l}7 \cdot 8^{\mathrm{a}} \\
26 \cdot 3^{\mathrm{b}} \\
98^{\mathrm{c}}\end{array}$ & $\begin{array}{c}0.5 \\
1.4 \\
15\end{array}$ & $\begin{array}{l}0.55^{\mathrm{a}} \\
1.98^{\mathrm{b}} \\
2.70^{\mathrm{c}}\end{array}$ & $\begin{array}{l}0.14 \\
0.30 \\
0.20\end{array}$ & $\begin{array}{r}7 \cdot 2^{\mathrm{a}} \\
24 \cdot 3^{\mathrm{b}} \\
96^{\mathrm{c}}\end{array}$ & $\begin{array}{l}0.5 \\
1.3 \\
15\end{array}$ \\
\hline
\end{tabular}

\footnotetext{
${ }^{a, b, c}$ Mean values within a column with unlike superscript letters were significantly different $(P<0.05)$.
}

${ }^{*}$ For details of diets see p. 562. 
Table 4. Effect of different dietary intakes of copper on intestinal absorption and balance of total zinc in rats (classical absorption and balance) ${ }^{*}$ (Values are means and standard errors for eight rats per group)

\begin{tabular}{|c|c|c|c|c|c|c|c|c|c|c|c|c|}
\hline \multirow[b]{2}{*}{ Dietary $\mathrm{Cu}(\mathrm{mg} / \mathrm{kg})$} & \multicolumn{2}{|c|}{$\begin{array}{c}\text { Zn intake } \\
(\mu \mathrm{g} / \mathrm{d})\end{array}$} & \multicolumn{2}{|c|}{$\begin{array}{l}\text { Faecal Zn } \\
\qquad(\mu \mathrm{g} / \mathrm{d})\end{array}$} & \multicolumn{2}{|c|}{$\begin{array}{c}\text { Zn absorption } \\
(\%)\end{array}$} & \multicolumn{2}{|c|}{$\begin{array}{l}\text { Zn absorption } \\
(\mu \mathrm{g} / \mathrm{d})\end{array}$} & \multicolumn{2}{|c|}{$\begin{array}{l}\text { Urinary Zn } \\
(\mu \mathrm{g} / \mathrm{d})\end{array}$} & \multicolumn{2}{|c|}{$\begin{array}{c}\text { Zn balance } \\
(\mu \mathrm{g} / \mathrm{d})\end{array}$} \\
\hline & Mean & SE & Mean & SE & Mean & SE & Mean & SE & Mean & SE & Mean & SE \\
\hline $\begin{array}{l}0.61 \\
7.41 \\
35.0\end{array}$ & $\begin{array}{r}946^{\mathrm{a}} \\
1050^{\mathrm{a}} \\
1106^{\mathrm{a}}\end{array}$ & $\begin{array}{r}106 \\
73 \\
48\end{array}$ & $\begin{array}{l}650^{\mathrm{a}} \\
758^{\mathrm{b}} \\
685^{\mathrm{a}}\end{array}$ & $\begin{array}{l}69 \\
45 \\
54\end{array}$ & $\begin{array}{l}31.9^{a} \\
27.8^{a} \\
37.8^{a}\end{array}$ & $\begin{array}{l}2.8 \\
3.1 \\
4.6\end{array}$ & $\begin{array}{l}296^{\mathrm{a}} \\
293^{\mathrm{a}} \\
420^{\mathrm{a}}\end{array}$ & $\begin{array}{l}55 \\
46 \\
58\end{array}$ & $\begin{array}{l}3 \cdot 4^{\mathrm{a}} \\
8 \cdot 1^{\mathrm{a}} \\
5 \cdot 5^{\mathrm{a}}\end{array}$ & $\begin{array}{l}0.6 \\
1.7 \\
1.5\end{array}$ & $\begin{array}{l}293^{\mathrm{a}} \\
284^{\mathrm{a}} \\
415^{\mathrm{a}}\end{array}$ & $\begin{array}{l}46 \\
46 \\
57\end{array}$ \\
\hline
\end{tabular}

a,b Mean values within a column with unlike superscript letters were significantly different $(P<0.05)$.

${ }^{*}$ For details of diets see p. 562.

Table 5. Effect of different dietary intakes of copper on intestinal absorption and balance of ${ }^{67}$ zinc isotope in rats (isotope absorption and balance) ${ }^{*}$ (Values are means and standard errors for eight rats per group)

\begin{tabular}{|c|c|c|c|c|c|c|c|c|c|c|c|}
\hline \multirow[b]{2}{*}{ Dietary $\mathrm{Cu}(\mathrm{mg} / \mathrm{kg})$} & \multirow{2}{*}{$\begin{array}{c}\begin{array}{c}{ }^{67} \mathrm{Zn} \text { intake } \\
(\mu \mathrm{g} / \mathrm{d})\end{array} \\
\text { Mean }\end{array}$} & \multicolumn{2}{|c|}{$\begin{array}{c}\text { Faecal }{ }^{67} \mathrm{Zn} \\
(\mu \mathrm{g} / \mathrm{d})\end{array}$} & \multicolumn{2}{|c|}{$\begin{array}{c}{ }^{67} \mathrm{Zn} \text { absorption } \\
(\%)\end{array}$} & \multicolumn{2}{|c|}{$\begin{array}{c}{ }^{67} \mathrm{Zn} \text { absorption } \\
(\mu \mathrm{g} / \mathrm{d})\end{array}$} & \multicolumn{2}{|c|}{$\begin{array}{l}\text { Urinary }{ }^{67} \mathrm{Zn} \\
(\mu \mathrm{g} / \mathrm{d})\end{array}$} & \multicolumn{2}{|c|}{$\begin{array}{c}{ }^{67} \mathrm{Zn} \text { balance } \\
(\mu \mathrm{g} / \mathrm{d})\end{array}$} \\
\hline & & Mean & SE & Mean & SE & Mean & SE & Mean & SE & Mean & SE \\
\hline $\begin{array}{l}0.61 \\
7.41 \\
35.0\end{array}$ & $\begin{array}{l}126 \cdot 5^{\mathrm{a}} \\
126 \cdot 5^{\mathrm{a}} \\
126 \cdot 5^{\mathrm{a}}\end{array}$ & $\begin{array}{l}90 \cdot 4^{\mathrm{a}} \\
91 \cdot 1^{\mathrm{a}} \\
84 \cdot 3^{\mathrm{b}}\end{array}$ & $\begin{array}{l}1.4 \\
1.6 \\
3.5\end{array}$ & $\begin{array}{l}28 \cdot 5^{\mathrm{a}} \\
28 \cdot 0^{\mathrm{a}} \\
33 \cdot 4^{\mathrm{a}}\end{array}$ & $\begin{array}{l}1 \cdot 1 \\
1 \cdot 3 \\
2 \cdot 8\end{array}$ & $\begin{array}{l}36 \cdot 1^{\mathrm{a}} \\
35 \cdot 4^{\mathrm{a}} \\
42 \cdot 2^{\mathrm{a}}\end{array}$ & $\begin{array}{l}1.4 \\
1.6 \\
3.5\end{array}$ & $\begin{array}{l}0.21^{\mathrm{a}} \\
0 \cdot 21^{\mathrm{a}} \\
0.15^{\mathrm{a}}\end{array}$ & $\begin{array}{l}0.08 \\
0.05 \\
0.05\end{array}$ & $\begin{array}{l}35 \cdot 9^{\mathrm{a}} \\
35 \cdot 2^{\mathrm{a}} \\
42 \cdot 1^{\mathrm{a}}\end{array}$ & $\begin{array}{l}1.3 \\
1.6 \\
3.5\end{array}$ \\
\hline
\end{tabular}

${ }^{a, b}$ Mean values within a column with unlike superscript letters were significantly different $(P<0.05)$.

* For details of diets see p. 562.

In the second part of this study, we clearly showed that a significant increase in absorption of $\mathrm{Cu}$ followed dietary $\mathrm{Cu}$ restriction whereas $\mathrm{Cu}$ supplementation was followed by only a slight decrease in $\mathrm{Cu}$ absorption in the rat. These results indicate that absorption of dietary $\mathrm{Cu}$ aims toward adaptation to a wide range of dietary $\mathrm{Cu}$ intakes, in particular to the low levels of $\mathrm{Cu}$ intakes. However, at the lowest amount of dietary $\mathrm{Cu}$ used in the present study $(0.61 \mathrm{mg} / \mathrm{kg})$ these adaptive mechanisms were not sufficient to maintain $\mathrm{Cu}$ status. There is only one report in the literature dealing with the $\mathrm{Cu}$ absorption in relation to different $\mathrm{Cu}$ intakes in the rat (Stuart et al. 1986). In agreement with our work, Stuart et al. (1986) observed that apparent $\mathrm{Cu}$ absorption was inversely related to dietary $\mathrm{Cu}$ intakes. Such results were also observed in some studies with human subjects using Cu stable isotopes (August et al. 1989; Turnlund et al. 1989, 1998). These authors showed that $\mathrm{Cu}$ absorption was dependent on dietary $\mathrm{Cu}$ intakes: the percentage absorbed decreased as dietary $\mathrm{Cu}$ increased, but the absolute absorbed $(\mathrm{mg} / \mathrm{d})$ increased as dietary $\mathrm{Cu}$ increased. Interestingly, in our work, the urinary excretion of either total $\mathrm{Cu}$ or ${ }^{65} \mathrm{Cu}$ isotope increased significantly in the $\mathrm{Cu}$-supplemented group, but without significant differences between the control and the $\mathrm{Cu}$-deficient groups.

In the present experiment, we also compared the classical approach with the isotopic approach for measuring the apparent absorption of total $\mathrm{Cu}$ or ${ }^{65} \mathrm{Cu}$ isotope respectively, based on the faecal monitoring of this element or isotope. The former is generally less accurate due to possible environmental contaminations, and takes into account all the endogenous excretion of $\mathrm{Cu}$ (desquamation of gastrointestinal tract, bile and pancreas secretions), whereas the second is more accurate and the contribution of the endogenous excretion of $\mathrm{Cu}$ is very low. The difference in the total $\mathrm{Cu}$ absorption between the $\mathrm{Cu}$-deficient and the
$\mathrm{Cu}$-supplemented groups was $16.5 \%$ whereas it was $44.9 \%$ as measured by ${ }^{65} \mathrm{Cu}$ absorption. In contrast to $\mathrm{Cu}$, apparent absorption values of total $\mathrm{Zn}$ and ${ }^{67} \mathrm{Zn}$ isotope were similar in the present study and may be explained in three ways: (1) the endogenous excretion of $\mathrm{Zn}$ is less important than that of $\mathrm{Cu}$ proportionally to their intake; $(2)$ the ${ }^{65} \mathrm{Cu}$ given as a liquid was better absorbed than the native $\mathrm{Cu}$ of the diet; and finally (3) the diet may have been contaminated with $\mathrm{Zn}$ during $\mathrm{Zn}$ analysis. Many studies have been performed to validate the extrinsic labelling approach, in particular for $\mathrm{Zn}$, with contradictory results. Even if it is still not certain that the isotope behaves in exactly the same way as the native $\mathrm{Cu}$ or $\mathrm{Zn}$ bound in the food matrix (Fairweather-Tait et al. 1991; Fox et al. 1994; Boza et al. 1995), it is accepted that extrinsic labels may be used as an approximate guide when assessing the bioavailability of $\mathrm{Cu}$ and $\mathrm{Zn}$ from different regimens.

Finally, many studies have noted the potential interaction between $\mathrm{Cu}$ and $\mathrm{Zn}$, particularly at their absorption level (Brewer et al. 1995; Rojas et al. 1996). Indeed, high Zn intakes have been reported to decrease $\mathrm{Cu}$ absorption, but little is known about the effect of high intakes of $\mathrm{Cu}$ on $\mathrm{Zn}$ absorption and excretion (O'Dell, 1989; Brewer, 1995). In the present study, a $\mathrm{Cu}$ intake 5-fold higher than the control level did not show any effects on intestinal absorption or urinary excretion of total $\mathrm{Zn}$ or ${ }^{67} \mathrm{Zn}$ isotope. However, the high level of $\mathrm{Cu}(35 \mathrm{mg} \mathrm{Cu} / \mathrm{kg}$ diet) remained lower than the level of $\mathrm{Zn}$ in the three experimental groups $(53 \mathrm{mg} \mathrm{Zn/kg}$ diet), which may explain this absence of effect of $\mathrm{Cu}$ intakes on $\mathrm{Zn}$ absorption and on its urinary excretion.

In conclusion, the plasma biomarkers of $\mathrm{Cu}$ status studied in the present work were affected more or less rapidly by low $\mathrm{Cu}$ intake and restored by return to control diet. Among these biomarkers, DAO activity was shown to react less rapidly to $\mathrm{Cu}$ deficiency than plasma $\mathrm{Cu}$ or caeruloplasmin 
concentrations. Further studies are still necessary to assess the sensitivity and specificity of DAO as a biomarker of $\mathrm{Cu}$ status. The present study also showed a significant increase in $\mathrm{Cu}$ intestinal absorption with dietary $\mathrm{Cu}$ restriction but no decrease with $\mathrm{Cu}$ supplementation in the rat.

\section{References}

August D, Janghorbani M \& Young VR (1989) Determination of zinc and copper absorption at three dietary $\mathrm{Zn}-\mathrm{Cu}$ ratios by using stable isotope methods in young adult and elderly subjects. American Journal of Clinical Nutrition 50, 1457-1463.

Bellanger J (1971) Dosage des oligoéléments dans les fourrages (Levels of trace elements in forages). Annales de la Nutrition et de l'Alimentation 25, B59-B96.

Boza JJ, Fox TE, Eagles J, Wilson PD \& Fairweather-Tait SJ (1995) The validity of extrinsic stable isotopic labeling for mineral absorption studies in rats. Journal of Nutrition 125, 1611-1616.

Brewer GJ (1995) Interactions of zinc and molybdenum with copper in therapy of Wilson's disease. Nutrition 11, Suppl. 1, 114-116.

Brewer GJ, Hill GM, Dick RD, Prasad AS \& Cossack ZT (1995) Interactions of trace elements: clinical significance. Journal of American College of Nutrition 4, 33-38.

Coudray C, Bousset C, Tressol JC, Pepin D \& Rayssiguier Y (1998) Short-term ingestion of chlorogenic or caffeic acids decreases zinc but not copper absorption in rats, utilization of stable isotopes and inductively-coupled plasma mass spectrometry technique. British Journal of Nutrition $\mathbf{8 0}$, $575-584$.

D'Agostino L, Ciacci C, Daniele B, Barone MV, Sollazzo R \& Mazzacca G (1984) Plasma diamine oxidase (DAO) and heparin. Digestive Disease Science 29, 1070-1071.

Danks DM (1988) Copper deficiency in humans. Annual Review of Nutrition 8, 235-237.

DiSilvestro RA, Jones AA, Smith D \& Wildam R (1997) Plasma diamine oxidase activities in renal dialysis patients, a human with spontaneous copper deficiency and marginally copper deficient rats. Clinical Biochemistry 30, 559-563.

Fairweather-Tait SJ, Fox TE, Wharf SG \& Eagles J (1991) Apparent zinc absorption by rats from foods labelled intrinsically and extrinsically with ${ }^{67} \mathrm{Zn}$. British Journal of Nutrition $\mathbf{6 6}$, $65-71$.

Fox TE, Fairweather-Tait SJ, Eagles J \& Wharf G (1994) Assessment of zinc bioavailability: studies in rats on zinc absorption from wheat using radio- and stable isotopes. British Journal of Nutrition 71, 95-101.

Jones AA, DiSilvestro RA, Coleman M \& Wagner TL (1997) Copper supplementation of adult men: effects on blood copper enzyme activities and indicators of cardiovascular disease risk. Metabolism 46, 1380-1383.

Klevay LM (1990) Ischemic heart disease: toward a unified theory. In Role of Copper in Lipid Metabolism, pp. 233-267 [KY Lei, editor]. Boca Raton, FL: CRC Press.

Klevay LM, Buchet JP, Bunker VW, Clayton BE, Gibson RS, Medeiros DM, Moser-Veillom PB, Patterson KY, Taper LJ \& Wolf WR (1993) Copper in the Western diet. In Trace Elements in Man and Animals. TEMA 8, pp. 207-210 [M Anke, D Meissner \& CF Mills, editors]. Gersdorf: Verlag Media Touristik.

Klevay LM, Reck SJ \& Barcome DF (1979) Evidence of dietary copper and zinc deficiencies. Journal of the American Medical Association 241, 1916-1918.

Kusche J, Trotha UV, Muhlberger G \& Lorenz W (1974) The clinical-chemical application of the NADPH test for the determination of diamine oxidase activity in human pregnancy. Agents Actions 4, 188-189.

Linder MC (1991) Biochemistry of copper. In Biochemistry of Elements, pp. 241-296 [E Freiden, editor]. New York, NY: Plenum.

Linder MC \& Hazegh-Azam M (1996) Copper biochemistry and molecular biology. American Journal of Clinical Nutrition 63, Suppl., 797S-811S.

Lo GS, Settle SL \& Steinke FH (1984) Bioavailability of copper in isolated soybean protein using the rat as an experimental model. Journal of Nutrition 114, 332-340.

Luk GD, Bayless TM \& Baylin SB (1980) Diamine oxidase (histaminase), a circulating marker for rat intestinal mucosal maturation and integrity. Journal of Clinical Investigation 66, 66-70.

Mills CF (1986) The dietary availability of copper in the form of naturally occurring organic complexes. Biochemistry Journal 63, 190-193.

Milne DB (1994) Assessment of copper status. Clinical Chemistry 40, 1479-1484.

Milne DB \& Johnson PE (1993) Assessment of copper status: effect of age and gender on references ranges in healthy adults. Clinical Chemistry 39, 883-887.

O'Connor JM, Bonham MP, Turley E, Kchoe C, Coulter JS, Faughnan MS, McKeown A, McKelvey-Martin VJ, Rock E, Rayssiguier Y, Mazur A, Flynn A, Cashman K, Baker A \& Strain JJ (1999) The effect of copper supplementation on putative indices of body copper status and on oxidative and inflammatory measures (FoodCue project). In Trace Elements in Man and Animals. TEMA 10, pp. 133 [A Favier, AM Roussel and R Anderson]. New York, NY: Plenum Press.

O'Dell BL (1989) Mineral interactions relevant to nutrient requirements. Journal of Nutrition 119, Suppl. 12, 1832-1838.

Oestreicher P \& Cousins RJ (1985) Copper and zinc absorption in the rat: mechanism of mutual antagonism. Journal of Nutrition 115, 159-166.

Pennington JAT \& Young BE (1991) Total diet study nutritional elements, 1982-1989. Journal of the American Dietetic Association 91, 179-183.

Rojas LK, McDowell LR, Cousins RJ, Martin FG, Wilkinson NS, Johnson AB \& Velasquez JB (1996) Interaction of different organic and inorganic zinc and copper sources fed to rats. Journal of Trace Elements in Medicine and Biology $\mathbf{1 0}$, 139-144.

Salmenpera L, Siimes MA, Nanto V \& Perheentupa J (1989) Copper supplementation: failure to increase plasma copper and ceruloplasmin concentrations in healthy infants. American Journal of Clinical Nutrition 50, 843-847.

Scheibel MS \& Mehta T (1985) Effect of dietary fiber on bioavailability of zinc and copper and histology in rats. Nutrition Research 5, 81-93.

Strain JJ (1994) Newer aspects of micronutrients in chronic disease: copper. Proceedings of the Nutrition Society 53, 583598.

Stuart MA \& Johnson PE (1986) Copper absorption and copper balance during consecutive periods for rats fed varying levels of dietary copper. Journal of Nutrition 116, 1028-1036.

Sunderman FM \& Nomoto S (1970) Measurement of human serum ceruloplasmin by its p-phenylenediamine oxidase activity. Clinical Chemistry 16, 903-910.

Takagi K, Nakao M, Ogura Y, Nabeshima T \& Kunii A (1994) Sensitive colorimetric assay of serum diamine oxidase. Clinica Chimica Acta 226, 67-75.

Tam CF, Kopple JD, Wang M \& Swendseid ME (1979) Diamine oxidase activity in plasma and in urine in uremia. Nephron 23, 23-27.

Turnlund JR, Keyes WR, Anderson HL \& Acord LL (1989) 
Copper absorption and retention in young men at three levels of dietary copper by use of stable isotope ${ }^{65} \mathrm{Cu}$. American Journal of Clinical Nutrition 49, 870-878.

Turnlund JR, Keyes WR, Peiffer GL \& Scott KC (1998) Copper absorption, excretion, and retention by young men consuming low dietary copper determined by using stable isotope ${ }^{65} \mathrm{Cu}$. American Journal of Clinical Nutrition 67, 1219-1225.

Wolvekamp MC \& de Bruin RW (1994) Diamine oxidase: an overview of historical biochemical and functional aspects. Digestive Disease 12, 2-14. 